\title{
The role of obesity in male fertility
}

\author{
Meltem Mermer ${ }^{1 *}$, Yasemin Akdevelioğlu² \\ ${ }^{1}$ Nutrition Support Unit, Dışkapı Yıldırım Beyazıt Training and Research Hospital, Ankara \\ ${ }^{2}$ Faculty of Health Sciences, Nutrition and Dietetics Department, Gazi University, Ankara
}

Received: 17 June 2018

Accepted: 24 July 2018

\section{*Correspondence:}

Dr. Meltem Mermer,

E-mail: meltemmermer@gmail.com

Copyright: $\odot$ the author(s), publisher and licensee Medip Academy. This is an open-access article distributed under the terms of the Creative Commons Attribution Non-Commercial License, which permits unrestricted non-commercial use, distribution, and reproduction in any medium, provided the original work is properly cited.

\begin{abstract}
Obesity causes many health problems as well as having negative effects on fertility. There is a multifaceted relationship between obesity and male infertility. Male fertility is associated with sperm concentration, motility and morphology. Testosterone (total and free) and gonadotropin levels were low and estrogen levels were found to be high in obese men. The decrease in androgen levels varies based on the degree of obesity. High body mass index is inversely related to total sperm count, sperm concentration, sperm morphology and number of motile sperm. Leptin and ghrelin are hormones that influence body weight regulation and eating behaviors. Serum leptin level, which is high in obese infertile men, showed a significant positive correlation with abnormal sperm morphology, serum FSH, LH, prolactin level and showed a significant negative correlation with sperm concentration, sperm motility and serum testosterone level. Further research is needed on the effects of ghrelin levels on male infertility. The relationship between obesity and erectile dysfunction can be explained by decreased testosterone levels and elevation of some proinflammatory cytokine levels. Decreased physical activity due to obesity, long-term sitting increases testicular temperature and affects sperm production negatively. There is a multifaceted relationship between obesity, metabolic syndrome and type 2 diabetes and serum testosterone and SHBG. Diet and exercise showed improvement in testosterone levels and sperm concentration due to decreased body weight. However, studies on this subject are extremely limited. The possible effects of weight loss on successful infertility treatment of obese men should not be ignored.
\end{abstract}

Keywords: Hypogonadism, Infertility, Male, Obesity, Sperm parameters

\section{INTRODUCTION}

The correlation between obesity and male infertility was first defined by Avicenna (Ibn Sina) in his book ElKanun fi't-Tib (The Cannon of Medicine). ${ }^{1}$ However, in the modern era, the correlation between obesity and male infertility has largely been ignored until recently. ${ }^{2}$

Today, a decline in semen quality resulting from the global dramatic lifestyle changes in modern society has once again drawn attention to this issue. ${ }^{3}$ Although the number of studies about the effects of obesity on reproductive function in men is limited, numerous new papers have recently been published describing the correlation between obesity and semen properties, reproductive endocrine function, sexual function and male infertility. ${ }^{2}$ Studies show that obesity changes semen parameters by causing reduced testicular volume and disrupting spermatogenesis. ${ }^{4-6}$ Furthermore, weight gain in men has been found to have a positive correlation with estradiol and a negative correlation with testosterone and SHBG (Sex hormone-binding globulin) levels. It has been reported that each $10 \mathrm{~kg}$ increase in a male's body weight increases the risk of fertility by $10 \%{ }^{7-11}$ It is for 
these adverse effects that obesity has become an alarming health issue facing modern society. ${ }^{3}$

This article aims to review studies regarding the role obesity, which has been established as a universal trend due to dramatic lifestyle changes in modern society, plays in male infertility and its effect mechanisms.

\section{OBESITY}

The term obesity comes from the word obesus which means "someone who has gotten fat by eating away" in Latin. It was first defined in Tobias Venner's book Via Recta in $1620 .^{12}$ World Health Organization defines obesity as Body Mass Index (BMI) $\geq 30 \mathrm{~kg} / \mathrm{m}^{2} .{ }^{13}$ Obesity has long been known be a major risk factor for many diseases particularly cardiovascular disease, diabetes, cancer and infertility.

\section{INFERTILITY}

Infertility affects roughly $15 \%$ of couples worldwide. While $20 \%-30 \%$ of all cases of infertility are only male related, males generally contribute to $50 \%$ of the cases. ${ }^{14}$ Infertility is defined as not getting pregnant following unprotected sex for a period of at least 12 months regardless of ultimately resulting in pregnancy. ${ }^{15}$

\section{CORRELATION BETWEEN OBESITY AND INFERTILITY PARAMETERS}

\section{Sperm parameters}

Male fertility is associated with sperm concentration, motility and morphology. ${ }^{16-18}$ Obesity causes a decrease in sperm concentration and motile sperm count in men. Hormone profiles of obese men are usually characterized by low testosterone (total and free), low gonadotropin levels [follicle stimulating hormone (FSH) and luteinizing hormone (LH)], elevated estrogen levels in circulation (usually estradiol and estrone). Obesity can cause spermatogenesis disruption due to hyperandrogenism and elevated estradiol levels. ${ }^{19}$ Peripheral aromatization of androgens in obese men causes an increase in both estradiol and estrone levels. As blood estrogen hormone levels increase, gonadotropinreleasing hormone $(\mathrm{GnRH})$ secretion in the hypothalamus decreases, while the secretion of gonadotropin hormones (FSH and LH) from the pituitary gland are inhibited. The inhibition of these hormones has an adverse effect on spermatogenesis. , $^{2,20-22}$

Three large-scale epidemiologic studies have determined a negative correlation between BMI and fertility in men. ${ }^{7,23,24}$ Studies have established a dose-response relation between BMI and infertility, plateauing over $\mathrm{BMI}>32-35 \mathrm{~kg} / \mathrm{m}^{2}{ }^{21}$

High BMI has been shown to have a negative correlation with total sperm count, sperm concentration, sperm morphology and motile sperm count. ${ }^{25,26}$ Another study focusing on the effect of obesity on sperm parameters in men has found that as BMI increases, so does the prevalence of men with low motile sperm count (normal body weight: $4.52 \%$, overweight: $8.93 \%$ and obese: $13.28 \%$ ) Similarly, incidence of oligozoospermia has been determined to increase with BMI (normal body weight: $5.32 \%$, overweight: $9.52 \%$ and obese: $15.62 \%) .{ }^{19}$ Studies have also found a negative correlation between total motile sperm count and body weight, waist and hip circumference. ${ }^{5,26,27}$

\section{Hormonal parameters}

Male hypogonadism is a syndrome caused by deterioration on one or more levels of the hypothalamicpituitary-gonadal axis resulting in decreased testosterone secretion and sperm count. ${ }^{28}$

Estrogens send negative feedback to the pituitary and hypothalamus causing diminished testosterone synthesis and changes in testicular function. ${ }^{29} \mathrm{~A}$ correlation between lower testosterone/estrogen ratio and infertility in humans has been established. A study by Pavlovich et al has shown that men with advanced infertility have significantly lower testosterone (T) and higher estradiol (E2) levels $(\downarrow \mathrm{T} / \mathrm{E} 2)$ compared to the fertile control group. ${ }^{30}$ Furthermore, higher body fat mass and central obesity are related to low serum testosterone and SHBG levels. ${ }^{5}$

\section{Inhibition of the hypothalamic-pituitary-gonadal axis}

Reproductive function begins with a signal provided by kisspeptin, a hypothalamic peptide. Kisspeptin affects the hypothalamic-pituitary-gonadal axis and plays an important role in fertility especially during puberty. ${ }^{31}$ Kisspeptins ensure the secretion of LH and FSH hormones from the anterior pituitary gland by stimulating GnRH secretion. Testosterone hormone is secreted when Leydig cells in the testes are stimulated by LH. In order for spermatogenesis to commence and to continue sertoli cells need to be stimulated by FSH causing the secretion of molecules such as SHBG and inhibin B. ${ }^{28,32}$

Sertoli cells provide germ cells which are developed with structural and hormonal support. The number of germ cells in adulthood is considered to be directly related to the number of functional sertoli cells. ${ }^{33}$ Inhibin $\mathrm{B}$ is secreted from sertoli cells boosting spermatogenesis. ${ }^{34}$

Even though the effect of obesity on certain gonadal functions in men is established, its effect on sertoli cell function is not entirely clear. Increased estradiol levels due to obesity are believed to cause gonadotropin suppression resulting in decreased $\mathrm{FSH}$ and $\mathrm{LH}$ hormone levels, lower FSH levels in return suppressing inhibin B synthesis from sertoli cells, all leading to compromised spermatogenesis. Studies have determined serum inhibin $\mathrm{B}$ levels in obese men to be low. ${ }^{33,35}$ 


\section{Leptin - ghrelin}

Leptin and ghrelin are hormones that play an important role in regulating body weight and eating behaviors. Leptin is a hormone secreted by adipocytes as body weight and fat mass increase. Leptin not only regulates GnRH secretion by stimulating the arcuate nucleus neurons of the hypothalamus, but also indirectly regulates the secretion of gonadotropins (FSH and $\mathrm{LH}$ ) from the pituitary. ${ }^{21}$ Leptin transport system in the blood brain barrier prevents high levels of leptin from reaching the hypothalamic receptors. The effect elevated leptin levels have on peripheral leptin receptors is the opposite of the one in the brain, causing decreased hormone production in the testes. ${ }^{36}$

Leptin levels in obese infertile men are higher than in obese fertile men. While serum leptin levels show a significant positive correlation with abnormal sperm morphology, serum FSH, LH, prolactin levels, they show a significant negative correlation with sperm concentration, sperm motility and serum testosterone levels. ${ }^{37}$ Leptin is the best indicator that androgen levels in obese men are decreased. ${ }^{21}$ A study by Zorn et al has established a negative correlation between serum leptin levels and inhibin B, total testosterone and SHBG levels. ${ }^{10}$

Ghrelin is a peptide which is secreted from the fundus of the stomach and which plays a role in regulating appetite. It is also known to be expressed in pancreas, placenta, kidneys, lungs, heart, pituitary, brain, ovaries and testes. Ghrelin has central gonadal effects on reproductive function. Ghrelin causes decreased FSH and LH secretion by inhibiting GnRH secretion. ${ }^{38}$ Hypogonadal men show lower levels of ghrelin than healthy men. ${ }^{39}$ Ghrelin is present at lower levels than serum in human seminal plasma. There is no difference in seminal plasma ghrelin levels of men with normospermia and dispermia.40 In their study, Pagatto et al have shown that ghrelin levels in circulation in hypogonadal men were significantly lower than in the overweight control group and that a positive correlation exists between ghrelin and total and free testosterone concentrations. ${ }^{41}$ This study has led to the conclusion that the correlation between ghrelin and androgens is independent from insulin resistance, body fat ratio and body composition.

Although it is believed that a potential interaction exists between sex hormones and leptin and ghrelin, further research is required about the effects the dysregulation of these hormones has on male infertility.

\section{Sexual dysfunction}

Another potential reason for infertility in obese men is the reduced frequency of sexual intercourse. Erectile dysfunction and low libido are the main reasons for sexual dysfunction in obese men. ${ }^{42}$ A study has found that obesity is 1.3 times higher a risk factor for erectile dysfunction. ${ }^{2}$ The European Male Ageing Study (EMAS) which studied the correlation between erectile dysfunction and BMI and waist circumference, discovered that $36.7 \%$ ( $p<0.001)$ of men with BMI $\geq 30$ $\mathrm{kg} / \mathrm{m}^{2}$ and $38.3 \%(\mathrm{p}<0.001)$ of men with waist circumference $\geq 102 \mathrm{~cm}$ had erectile dysfunction. ${ }^{43}$

The link between obesity and erectile dysfunction is explained by reduced testosterone levels and increased levels of some proinflammatory cytokines in obese individuals. Inflammation markers have been found to have positive correlation with endothelial dysfunction. ${ }^{2}$

\section{Testicular temperature}

Even a $1-1.5^{\circ} \mathrm{C}$ increase in scrotal temperature causes a reduction in testicle size, leading to lower sperm production and changes in sperm morphology. Although actual effects of scrotal temperature on testicular function are still unclear, it may be linked to infertility.44 Obesity and resulting physical inactivity, long-term sitting have an adverse effect on sperm production by increasing testicular temperature. ${ }^{45}$

\section{INSULIN RESISTANCE, METABOLIC SYNDROME AND TYPE 2 DIABETES MELLITUS}

Obesity not only increases the risk for insulin resistance and developing type 2 diabetes, but it also plays a central role in diagnosing metabolic syndrome. ${ }^{46,47}$ Independent of insulin resistance, low concentrations of testosterone and SHBG have a significant correlation with abdominal obesity and high concentrations of triglycerides, which are components of metabolic syndrome. ${ }^{48,49}$ The reverse correlation between testosterone and insulin resistance is a result of adipose tissue independent of SHBG. ${ }^{50}$ As for the relationship between SHBG and metabolic syndrome, it is believed to be caused by insulin resistance. It is suggested that insulin inhibits hepatic SHBG synthesis, thus low SHBG is a result of insulin resistance, not the cause. $^{51}$ Obesity indicates low testosterone and SHBG levels in men, which in turn indicate intra-abdominal fat build-up, development of central obesity and risk for metabolic syndrome in men. ${ }^{52}$

Androgens are important indicators of body composition in men that promote lean mass growth and suppress fat deposits. There is a bi-directional correlation between low testosterone levels and obesity in men. ${ }^{52}$ Although the exact mechanisms are unknown, testosterone is believed to inhibit lipid intake and to reduce visceral fat tissue accumulation by reducing lipoprotein lipase activity. Testosterone treatment has shown a decrease in visceral fat tissue accumulation and an increase in lean body mass. $^{49}$

There is a multifaceted correlation between obesity, metabolic syndrome and type 2 diabetes and serum testosterone and SHBG. An increase in the production of adipokines, cytokines and other proinflammatory factors 
mainly resulting from visceral adipocytes and macrophages is seen in case of obesity. These factors disrupt the insulin response in fat, liver and endothelial functions, resulting in metabolic syndrome, type 2 diabetes, erectile dysfunction and cardiovascular disease. Many men with type 2 diabetes, especially those who are obese, have low levels of serum total testosterone and SHBG. ${ }^{53}$

\section{EFFECTS OF WEIGHT LOSS}

Increased testosterone levels and improved sperm concentration were observed in obese men due to body weight loss through diet and exercise. ${ }^{21,25}$

Data which might explain the effects of losing weight on sperm production and fertility is limited. Majority of the studies have shown that weight loss improves the hormone profile (testosterone, SHBG) linked to reproduction and that this improvement lasts approximately 12 months. ${ }^{28,54-56}$ Higher ratio of body weight loss leads to greater increase in androgen levels. ${ }^{57}$

A positive correlation has been shown to exist between obesity and endothelial dysfunction and increased serum concentrations of vascular inflammatory markers. In a study designed to test the hypothesis that lifestyle changes aimed at reducing body weight and increasing physical activity shall improve erectile and endothelial functions in obese men, roughly one third of the obese men who initially had erectile dysfunction reported improvement in sexual function due to lifestyle changes. ${ }^{58}$

Hypogonadism, which is quite prevalent in morbidly obese men, has been reported to reverse following weight loss achieved through bariatric surgery. ${ }^{59}$ In other studies, weight loss through gastroplasty has been linked to improving the abnormal hormonal profile in overweight men, as well as improving the quality of their sex lives by increasing SHBG, total and free testosterone levels and decreasing E2 levels. ${ }^{60-63}$ Conversely, in some cases, deterioration of sperm parameters was reported following bariatric surgery. Although vitamin and mineral supplementation is recommended following any type of bariatric surgery, deficiency of nutrients needed for spermatogenesis is considered to have possible adverse effects on sperm parameters. ${ }^{64,65}$

\section{CONCLUSION}

As well as causing the development of numerous diseases, obesity also has an adverse effect on male fertility. Studies focusing on the correlation between obesity and male infertility show that obesity essentially causes deterioration in sperm parameters, hormonal changes and sexual dysfunction. Infertility parameters in said studies improved as a result of weight loss following the implementation of a dietary treatment regimen geared towards losing weight. Although research on this subject is limited, possible effects of weight loss on successful infertility treatment of obese men should not be ignored. Therefore, further research is needed to assess the effects of body weight normalization through diet modification, physical activity or bariatric surgery on male infertility.

\section{Funding: No funding sources \\ Conflict of interest: None declared \\ Ethical approval: Not required}

\section{REFERENCES}

1. Abdel-Halim RE. Obesity. 1000 years ago. Lancet. 2005;366(9481):204.

2. Hammoud AO, Gibson M, Peterson CM, Meikle AW, Carrell DT. Impact of male obesity on infertility: a critical review of the current literature. Fertil Steril. 2008;90(4):897-904.

3. Atif K. Mechanisms linking obesity to male infertility. Cent European J Urol. 2015;68(1):79-85.

4. Kort HI, Massey JB, Elsner CW, Mitchell- Leef D, Shapiro DB, Witt MA, et al. Impact of body mass index values on sperm quantity and quality. $\mathbf{J}$ Androl. 2006;27(3):450-2.

5. MacDonald AA, Herbison GP, Showell M, Farquhar CM. The impact of body mass index on semen parameters and reproductive hormones in human males: a systematic review with meta-analysis. Hum Reprod Update. 2010;16(3):293-311.

6. Jensen TK, Andersson AM, Jørgensen N, Andersen AG, Carlsen E, Petersen JH, et al. Body mass index in relation to semen quality and reproductive hormones among 1,558 Danish men. Fertil Steril. 2004;82(4):863-70.

7. Sallmén M, Sandler DP, Hoppin JA, Blair A, Baird DD. Reduced fertility among overweight and obese men. Epidemiology. 2006;17(5):520-3.

8. Magnusdottir EV, Thorsteinsson T, Thorsteinsdottir S, Heimisdottir M, Olafsdottir K. Persistent organochlorines, sedentary occupation, obesity and human male subfertility. Hum Reprod. 2005;20(1):208-15.

9. Hanafy S, Halawa FA, Mostafa T, Mikhael NW, Khalil KT. Serum leptin correlates in infertile oligozoospermic males. Andrologia. 2007;39(5):17780 .

10. Zorn B, Osredkar J, Meden-Vrtovec H, Majdic G. Leptin levels in infertile male patients are correlated with inhibin B, testosterone and SHBG but not with sperm characteristics. Int J Androl. 2007;30(5):43944.

11. Chavarro JE, Toth TL, Wright DL, Meeker JD, Hauser R. Body mass index in relation to semen quality, sperm DNA integrity, and serum reproductive hormone levels among men attending an infertility clinic. Fertil Steril. 2010:93(7);2222-31.

12. Barnett R. Historical Keywords: Obesity. Lancet. 2005;365(9474):1843. 
13. World Health Organization: Obesity: preventing and managing the global epidemic. 2000, Geneva: WHO Technical Report Series number 894.

14. Agarwal A, Mulgund A, Hamada A, Chyatte MR. A unique view on male infertility around the globe. Reprod Biol Endocrinol. 2015;13(1):37-45.

15. Cloonan, YK, Holt, VL, Goldberg, J. Male factor infertility: A twin study. Perinatal Epidemiol. 2007;21(3):229-34.

16. Bonde JP, Ernst E, Jensen TK, Hjollund NH, Kolstad $\mathrm{H}$, Henriksen $\mathrm{TB}$, et al. Relation between semen quality and fertility: a population-based study of 430 first-pregnancy planners. Lancet. 1998;352(9135):1172-77.

17. Slama R, Eustache F, Ducot B, Jensen TK, Jorgensen N, Horte A, et al. Time to pregnancy and semen parameters: a cross-sectional study among fertile couples from four European cities. Hum Reprod. 2002;17(2):503-15.

18. Guzick DS, Overstreet JW, Factor-Litvak P, Brazil CK, Nakajima ST, Coutifaris C, et al. Sperm morphology, motility, and concentration in fertile and infertile men. $\mathrm{N}$ Engl $\mathrm{J}$ Med. 2001;345(19):1388-93.

19. Hammoud AO, Wilde N, Gibson M, Parks A, Carrell DT, Meikle AW. Male obesity and alteration in sperm parameters. Fertil Steril. 2008;90(6):2222-5.

20. Akingbemi BT. Estrogen regulation of testicular function. Reprod Biol Endocrinol. 2005;3(1):51-63.

21. Tremellen K, Pearce K. The Effect of Obesity on Male Reproductive Function. Nutrition, Fertility and Human Reproductive Function. $1^{\text {st }}$ ed. Florida:CRC Press; 2015.191-211.

22. De Boer H, Verschoor L, Ruinemans-Koerts J, Jansen M. Letrozole normalizes serum testosterone in severely obese men with hypogonadotropic hypogonadism. Diab Obesity Metabol. 2005;7(3):211-5.

23. Ramlau-Hansen $\mathrm{CH}$, Thulstrup AM, Nohr EA, Bonde JP, Sørensen TI, Olsen J. Subfecundity in overweight and obese couples. Hum Reprod. 2007;22(6):1634-7.

24. Nguyen RH, Wilcox AJ, Skjærven R, Baird DD. Men's body mass index and infertility. Hum Reprod. 2007;22(9):2488-93.

25. Håkonsen LB, Thulstrup AM, Aggerholm AS, Olsen J, Bonde JP, Andersen CY, et al. Does weight loss improve semen quality and reproductive hormones? Results from a cohort of severely obese men. Reprod Health. 2011;8(1); 24-32.

26. 26. Sermondade N, Faure C, Fezeu L, Shayeb AG, Bonde JP, Jensen TK, et al. BMI in relation to sperm count: an updated systematic review and collaborative meta-analysis. Hum Reprod Update. 2012;19(3):221-31.

27. Fejes I, Koloszar S, Szollosi J, Zavaczki Z, Pal A. Is semen quality affected by male body fat distribution? Andrologia. 2005;37(5):155-9.

28. Mihalca R, Fica S. The impact of obesity on the male reproductive axis. J Med Life. 2014;7(2):296-300.
29. Luboshitzky R, Kaplan-Zverling M, Shen-Orr Z, Nave $R$, Herer P. Seminal plasma androgen/oestrogen balance in infertile men. Int $\mathrm{J}$ of Andrology. 2002;25(6):345-51.

30. Pavlovich CP, King P, Goldstein M, Schlegel PN. Evidence of a treatable endocrinopathy in infertile men. J Urol. 2001;165(3):837-41.

31. Head IM, Eyigör Ö. Kisspeptins and Kisspeptin Neurons: Effects on the Reproductive System and Hypothalamic Placements. J Uludag Uni Faculty of Med. 2011; 37 (1): 53-60.

32. Koyun E. Obezitenin sperm effect on functions (Derleme). Androl Bülten.2013;15(54):185-9.

33. Winters SJ, Wang C, Abdelrahaman E, Hadeed V, Dyky MA, Brufsky A. Inhibin-B levels in healthy young adult men and prepubertal boys: is obesity the cause for the contemporary decline in sperm count because of fewer Sertoli cells? J Androl. 2006;27(4):560-4.

34. Kumanov P, Nandipati K, Tomova A, Agarwal A. Inhibin $\mathrm{B}$ is a better marker of spermatogenesis than other hormones in the evaluation of male factor infertility. Fertil Steril. 2006;86(2):332-38.

35. Globerman H, Shen-Orr Z, Karnieli E, Aloni Y, Charuzi I. Inhibin B in men with severe obesity and after weight reduction following gastroplasty. Endocr Res. 2005;31(1):17-26.

36. Caprio M, Fabbrini E, Isidori AM, Aversa A, Fabbri A. Leptin in reproduction. Trends in Endocrinol Metabol. 2001;12(2):65-72.

37. Hofny ER, Ali ME, Abdel-Hafez HZ, Kamal EE, Mohamed EE, El-Azeem HG, et al. Semen parameters and hormonal profile in obese fertile and infertile males. Fertil Steril. 2010;94(2):581-4.

38. Dupont J, Maillard V, Coyral-Castel S, Ramé C, Froment P. Ghrelin in female and male reproduction. Int J Peptides. 2010;2010:1-8.

39. Duran C, Yonem A, Ustun I, Ozcan O, Ipcioglu OM, Basekim CC. Plasma ghrelin levels in males with idiopathic hypogonadotropic hypogonadism. Endocrine. 2008;34(1-3):81-6.

40. Panidis D, Goulis DG, Katsikis I, Koliakos G, Georgopoulos NA, Diamanti-Kandarakis E. Serum and seminal plasma ghrelin levels in men with normospermia and dyspermia. Gynecol Endocrinol. 2008;24(6):320-5.

41. Pagotto U, Gambineri A, Pelusi C, Genghini S, Cacciari M, Otto B, et al. Testosterone replacement therapy restores normal ghrelin in hypogonadal men. J Clin Endocrinol Metabol. 2003; 88:4139-43.

42. Kolotkin RL, Zunker C, Østbye T. Sexual functioning and obesity: a review. Obesity. 2012;20(12):2325-33.

43. Han TS, Tajar A, O'Neill TW, Jiang M, Bartfai G, Boonen $S$, et al. Impaired quality of life and sexual function in overweight and obese men: the European Male Ageing Study. Eur J Endocrinol. 2011;164:1003-1011.

44. Garolla A, Torino M, Miola P, Caretta N, Pizzol D, Menegazzo M, et al. Twenty-four-hour monitoring of 
scrotal temperature in obese men and men with a varicocele as a mirror of spermatogenic function. Hum Reprod. 2015;30(5):1006-13.

45. Ivell R. Lifestyle impact and the biology of the human scrotum. Reprod Biol Endocrinol. 2007;5(1):15-29.

46. Kahn SE, Hull RL, Utzschneider KM. Mechanisms linking obesity to insulin resistance and type 2 diabetes. Nature. 2006;444(7121):840.

47. Després JP, Lemieux I. Abdominal obesity and metabolic syndrome. Nature. 2006;444(7121):881.

48. Li C, Ford ES, Li B, Giles WH, Liu S. Association of testosterone and sex hormone-binding globulin with metabolic syndrome and insulin resistance in men. Diabetes Care. 2010;33(7):1618-24.

49. Allan CA, Strauss BJ, Burger HG, Forbes EA, McLachlan RI. Testosterone therapy prevents gain in visceral adipose tissue and loss of skeletal muscle in nonobese aging men. J Clin Endocrinol Metab. 2008;93:139-46.

50. Tsai EC, Matsumoto AM, Fujimoto WY, Boyko EJ. Association of bioavailable, free, and total testosterone with insulin resistance. Diabetes Care. 2004;27(4):861-8.

51. Wallace IR, McKinley MC, Bell PM, Hunter SJ. Sex hormone binding globulin and insulin resistance. Clin Endocrinol. 2013;78(3):321-9.

52. Allan CA, McLachlan RI. Androgens and obesity. Current Opinion in Endocrinology, Diabetes Obesity. 2010;17(3):224-32.

53. Wang C, Jackson G, Jones TH, Matsumoto AM, Nehra A, Perelman MA, et al. Low testosterone associated with obesity and the metabolic syndrome contributes to sexual dysfunction and cardiovascular disease risk in men with type 2 diabetes. Diabetes Care. 2011;34(7):1669-75.

54. Kaukua J, Pekkarinen T, Sane T, Mustajoki P. Sex hormones and sexual function in obese men losing weight. Obes Res. 2003;11(6):689-94.

55. Luboshitzky R, Lavie L, Shen-Orr Z, Herer P. Altered luteinizing hormone and testosterone secretion in middle-aged obese men with obstructive sleep apnea. Obes Res. 2005;13(4):780-6.

56. Niskanen L, Laaksonen DE, Punnonen K, Mustajoki $\mathrm{P}$, Kaukua J, Rissanen A. Changes in sex hormonebinding globulin and testosterone during weight loss and weight maintenance in abdominally obese men with the metabolic syndrome. Diabetes Obes Metab. 2004;6(3):208-15.
57. Corona G, Rastrelli G, Monami M, Saad F, Luconi M, Lucchese M, et al. Body weight loss reverts obesity-associated hypogonadotropic hypogonadism: a systematic review and meta-analysis. Eur $\mathrm{J}$ Endocrinol. 2013;168(6):829-43.

58. Esposito K, Giugliano F, Di Palo C, Giugliano G, Marfella R, D'Andrea F, et al. Effect of lifestyle changes on erectile dysfunction in obese men: a randomized controlled trial. JAMA. 2004;291(24):2978-84.

59. Pellitero S, Olaizola I, Alastrue A, Martínez E, Granada ML, Balibrea JM, et al. Hypogonadotropic hypogonadism in morbidly obese males is reversed after bariatric surgery. Obesity Surg. 2012;22(12):1835-42.

60. Reis LO, Favaro WJ, Barreiro GC, De Oliveira LC, Chaim EA, Fregonesi A, et al. Erectile dysfunction and hormonal imbalance in morbidly obese male is reversed after gastric bypass surgery: a prospective randomized controlled trial. Int $\mathbf{J}$ Androl. 2010;33(5):736-44.

61. Bastounis EA, Karayiannakis AJ, Syrigos K, Zbar A, Makri G, Alexiou D. Sex hormone changes in morbidly obese patients after vertical banded gastroplasty. Eur Surg Res. 1998;30(1):43-47.

62. Globerman H, Shen-Orr Z, Karnieli E, Aloni Y, Charuzi I. Inhibin B in men with severe obesity and after weight reduction following gastroplasty. Endocr Res. 2005;31(1):17-26.

63. Hammoud A, Gibson M, Hunt SC, Adams TD, Carrell DT, Kolotkin RL, et al. Effect of Roux-en-Y gastric bypass surgery on the sex steroids and quality of life in obese men. J Clin Endocrinol Metabol. 2009;94(4):1329-32.

64. di Frega AS, Dale B, Di Matteo L, Wilding M. Secondary male factor infertility after Roux-en-Y gastric bypass for morbid obesity: case report. Hum Reprod. 2005;20:997-98.

65. Sermondade N, Massin N, Boitrelle F, Pfeffer J, Eustache F, Sifer C, et al. Sperm parameters and male fertility after bariatric surgery: three case series. Reprod Biomed Online. 2012;24(2):206-10.

Cite this article as: Mermer M, Akdevelioğlu Y. The role of obesity in male fertility. Int J Reprod Contracept Obstet Gynecol 2018;7:3435-40. 